\title{
Republic of Macedonia or North Macedonia?
}

\author{
ZHIDAS DASKALOVSKI
}

ABSTRACT Before Macedonia even became an independent state, Greece objected to its existence under such a name. The Greek challenge to the name, 'Republic of Macedonia' is a smokescreen over Greek objections to the very existence of the Macedonian state and nation. The freeing up of the Macedonian accession process into the EU and NATO should never undermine the right of the nation to its own existence. The Prespa Agreement, while ostensibly resolving the 'name dispute,' has disturbing ramifications for the interpretation of Macedonian history, Macedonian identity, and Macedonian language and culture.

\section{Introduction}

ncyclopedia Britannica notes that literally, "Europa" is thought to have meant "Mainland", an appropriate designation of the broadening, extensive northerly lands that lay beyond Greece, lands with characteristics but vaguely known... clearly different from those inherent in the concepts of Asia and Libya, both of which, relatively prosperous and civilized, were associated closely with the culture of the Greeks and their predecessors. Among the lands north of Greece today is also (the Republic of) Macedonia. Or is it? Since its independence in 1991, the coun- try's name has been vigorously disputed by its southern neighbor. For more than twenty years the naming dispute remained unresolved, despite the UN-sponsored talks between the countries on the differences over the name. Last year Macedonia and Greece signed an agreement which regulates that the name of the country is North Macedonia. Has this agreement signed at the Prespa Lake ended the dispute? The answer is no. The name change is illegitimate and essentially unsustainable over the long term, creating only a dangerous precedent by running counter imperative to international legal norms (ius cogens).
* University of Kliment Ohridski, North Macedonia 2019, pp. 63-73 
If we speak about a person's ethnonational belonging, then

a Macedonian is someone who lives in the Republic of Macedonia, or in Aegean or Pirin Macedonia, or elsewhere around the world for that matter, and chooses to belong to the Macedonian nation

\section{The Macedonian Position on the 'Naming Dispute' until 2016}

From the Macedonian perspective, the dispute is impossible to solve amicably due to the fact that in essence, it is an argument over cultural-historical identities relating to the right of self-identification of all the peoples in the regions of Macedonia. That is, the right of the majority population of Macedonia to identify itself as 'Macedonian' by ethnonational belonging, and the right of the Greeks and Bulgarians in the Macedonian regions of these countries also to be identified as 'Macedonian.' This element of the dispute also relates to the right to label the Macedonian language as such. Moreover, it also pertains to the "right" to depict ancient Macedon history as being an integral part of the ethnogenesis of the Greek and/or Macedonian nation. This is a clash over historical narratives and the right to claim the origins of the Macedonian ethnic group and nation today and in the ancient past.

The demand on Macedonia to change its name, in effect, is without precedent and any justifiable cause. Macedonia has a legitimate right to its name and identity. This right is based on various arguments, be they legal, moral, historical, or grounded in liberal-democratic ideas. The simplest Macedonian argument regarding the name dispute is that the case is unambiguous as there are no two states claiming the same nationality and the same name; a regional identity [in Greece] should not be mixed with an ethnonational identity in Macedonia. There cannot be confusion between a country and a region; the name "Macedonia" is used by Greece to designate one of its provinces which is not an international legal entity. In that context, there is a simple answer to the question 'who is/can be a Macedonian today?' If we speak about a person's ethnonational belonging, then a Macedonian is someone who lives in the Republic of Macedonia, or in Aegean or Pirin Macedonia, or elsewhere around the world for that matter, and chooses to belong to the Macedonian nation. Macedonians by citizenship, on the other hand, are all those living in the Republic of Macedonia regardless of their choice of ethnonational belongings. A Macedonian is also someone from any of the three regions of Macedonia who chooses to develop a regional Macedonian identity regardless of his/her own citizenship or ethno-national belonging. Thus, Aleksandar from Skopje, Mehmet from Tetovo, Jane 


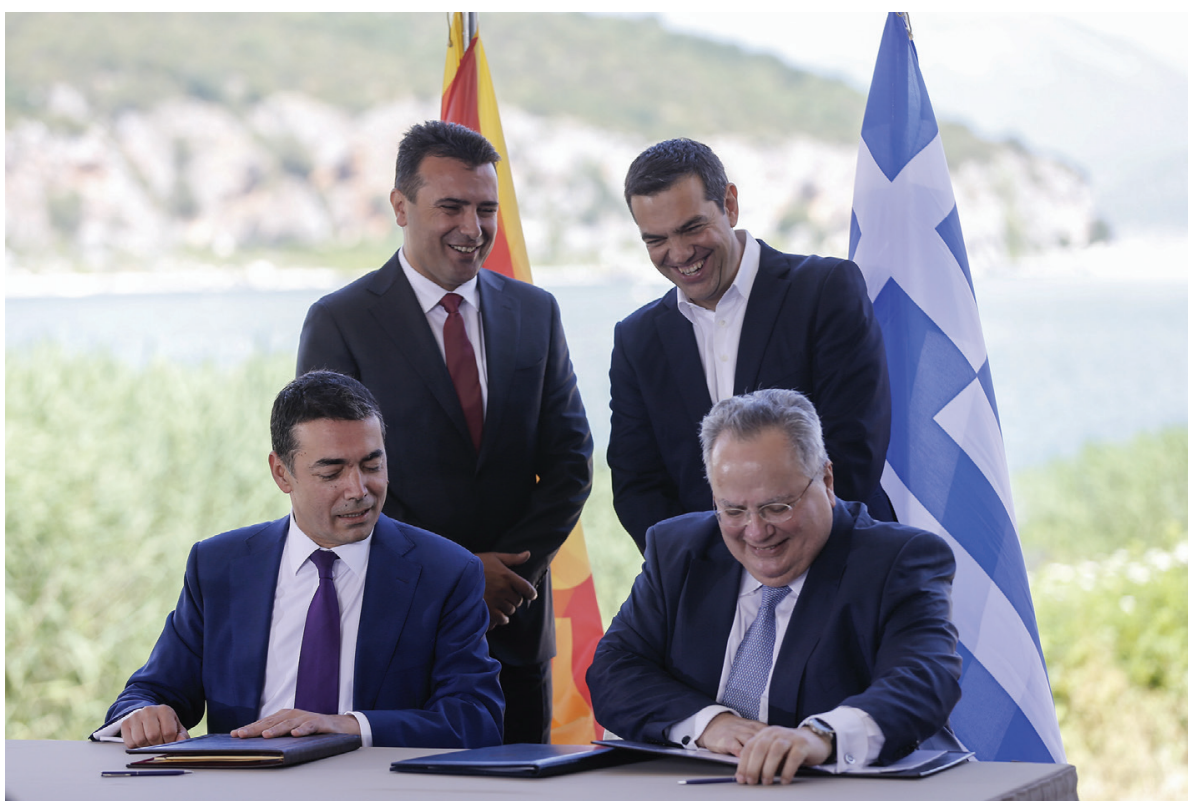

Greek Foreign Minister Nikos Kotzias (R) and his Macedonian counterpart Nikola Dimitrov (L) signed the Prespa Agreements on June 17, 2018. AYHAN MEHMET / AA Photo

from Petrich, Asparuh from Blagoevgrad, Yorios from Thessaloniki, and Atanas from Florina are all Macedonians and there is nothing wrong with that. Thus, while Aleksandar, Jane, and Atanas are all Macedonians sharing the same (ethno) national feelings; only Aleksandar and Mehmet are Macedonians by citizenship, while Asparuh and Yorios are regionally Macedonians who have Bulgarian and Greek national feelings and citizenships respectively. Although Macedonians are most commonly referred to as those with Macedonian ethnonational feelings, there is nothing wrong nor disturbing in the fact that others might be referred to as Macedonians based on their identification with the Macedonian region or citizenship. In addition, it is clear that the Republic of Macedonia has no claims on the larger region by the same name. The country accepts the existing borders and has no territorial claims against any of its neighbors. Even though some extreme Macedonian nationalists may dream about or continue to voice the dream of Great Macedonia, the state does not possess the means to threaten any of its neighbors, let alone challenge the existing territorial status quo. It has publicly, formally, and repeatedly disavowed any territorial claim on Greek lands since the Greeks first made their accusations.

Given this clarification, then, what is the problem with the declared identity of Macedonians? What is the problem with being Macedonian evidenced by the persistent and forceful efforts by the Greek and Bulgarian governments to convince Atanas and Jane that they cannot have Macedonian national feelings? Ever since the partition of Macedonia in the Balkan 
wars of 1912-1913, Athens and Sofia, and Belgrade until the Second World War, have employed chauvinistic policies to prevent the development and nourishment of a Macedonian national sentiment. To call the dispute a dispute over the name is a euphemism which conceals the Greek objections, in some cases direct and open and in others indirect and veiled, to the very existence of the Macedonian state and nation. Indeed, Greece denies the existence of a Macedonian nation and Macedonian minority on its territory because such a recognition would run counter to the templates of ethnic homogeneity and purity that define Greek ethnic nationalism and the Greek concept of citizenship.

Another argument in defense of the right of Macedonia to use its name is the right to self-determination. Self-determination is a principle, often seen as a moral and legal right, that: "all peoples have the right [to] freely determine their political status and freely pursue their economic, social and cultural development." Remier writes, "it seems that implicit at least within self-determination lies an acknowledgement that peoples, at the minimum may freely pursue their own forms of culture and identity... it would follow that it is for these peoples to determine the content of their culture or identity, including their collective name."2 Alternatively put,

A state should have the right to establish its own constitutional system in conformity with obligations imposed by international law (for example, with respect to human rights treaties), and to choose its own national symbols including both its name and its flag... the subject of the dispute between Greece and Macedonia clearly relates to an issue which, as a matter of sovereignty, should fall exclusively within the discretion of Macedonia itself. ${ }^{3}$

Traditionally, from the point of view of public international law, states may: "call themselves whatever they wish because a state's name is fundamentally a purely domestic matter, and it is a bedrock principle that every state 'has the right freely to choose and develop its political, social, economic and cultural systems."' 4 There appears to be: "no basis in international law or practice for the Greek demand that Macedonia change its name, claiming that the right to use that name should belong exclusively to Greece." In fact, all Macedonian governments until 2016 used some of the arguments outlined above in their diplomatic struggle with Greece. Since 2016, the social democrat Macedonian government has undertaken a different course of action, trying to accommodate certain Greek demands in order to be allowed to accede to NATO and start negotiations with the EU. This new policy resulted in an agreement between Skopje and Athens on the issue in the spring of 2018.

\section{Breaking Laws to Get to the Prespa Agreement}

The Prespa Agreement was signed on June 17, 2018 at a high-level ceremony in the Greek border village of Psarades on Lake Prespa, by the two 
foreign ministers, Nikola Dimitrov and Nikos Kotzias, and in the presence of the respective Prime Ministers, Zoran Zaev and Alexis Tsipras. Accordingly, Macedonia is being renamed the Republic of North Macedonia with the new name to be used domestically, as well as in all bilateral relations and in all regional and international organizations and institutions. The deal includes recognition of the Macedonian language as being Slavic, and the citizenship of the country as "Macedonian/citizen of the Republic of North Macedonia." There is an explicit clarification that the citizens of the country are not related to the ancient Macedonians (Article 7). All public institutions, as well as state-funded cultural organizations will be defined by the term "Northern Macedonia." Additionally, the agreement stipulates the removal of the Vergina Sun from public use in Macedonia and the formation of a committee for the review of school textbooks and maps in both countries for the removal of irredentist content and to align them with UNESCO and Council of Europe standards.

While Athens immediately informed the EU and NATO that Greece no longer objects to Macedonia's Euro-Atlantic accession under the new name; in Macedonia, the ruling coalition ratified the Prespa Agreement with a majority vote (69 votes out of 120 , with no consent from the opposition) on June 20, 2018. President Ivanov decided not to sign the decree promulgating the law ratifying the deal by pointing out that "the agreement has no constitutional ground

\section{The freeing up of the} Macedonian accession process into the EU and NATO should never undermine the right of the nation to its own existence

and is not ratified in compliance with the Constitution."6 Dimitrov's signature violates Article 119 (1) of the Constitution according to which "international treaties are signed by the President of the Republic, in the name of the Republic of Macedonia."

In spite of the repeated positive vote in the Parliament, Ivanov has used the so-called 'pocket veto', and never signed the decree. Nonetheless, the Prespa changes were put to a "consultative/advisory" referendum in the autumn of 2018. There were serious breaches of national legislation and the Code of Good Referendum Practices of the Venice Commission. The referendum question was misleading and open for interpretation, and experts wondered how there could be consultation if the agreement was already ratified. Article 73 of the Constitution explicitly determines that a decision made in a referendum is binding, and the decision in a referendum is adopted on condition that more than half of the total number of voters votes $(50 \%+1)$.

In the referendum, 91 percent of voters voted in favor with a 37 percent 
The Prespa Agreement deals

with the interpretation

of Macedonian history,

Macedonian identity,

Macedonian language, and

culture. It has ramifications

on the Constitutional

order, political system, and

education, and denies the

individual and group right

to self-determination of

Macedonians
On October 19, 2018, the parliament voted to start the process of renaming the country "North Macedonia," after a total of $80 \mathrm{MPs}$ voted in favor of the constitutional changes. On January 11,2019 , it completed the legal implementation of the Prespa Agreement by approving the constitutional changes for renaming the country to North Macedonia with a two-thirds parliamentary majority (81 MPs). To achieve the necessary majority, the ruling coalition bribed, intimidated, and blackmailed MPs, made changes to the Criminal Code, and pardoned MPs. During the ratification process, the Parliamentary Rule Book was violated. On January 25, 2019, Greece's Parliament approved the Agreement with 153 votes in favor and 146 votes against with 1 abstention and shortly enacted a law of the Prespa Agreement. On February 6, 2019, NATO's 29 members signed the accession protocol with the future Republic of North Macedonia.

\section{No to the Prespa Agreement}

Macedonians have for generations identified with Macedonia. Songs, stories, books, and films had been made on the idea of Macedonia becoming an independent state years before 1944 when the Republic became part of the Federal Yugoslavia. To deny them the right to call their country Macedonia is immoral. The freeing up of the Macedonian accession process into the EU and NATO should never undermine the right of the nation to its own existence. Changing the name not only violates 


\section{STOP THE GREEK RACISM}

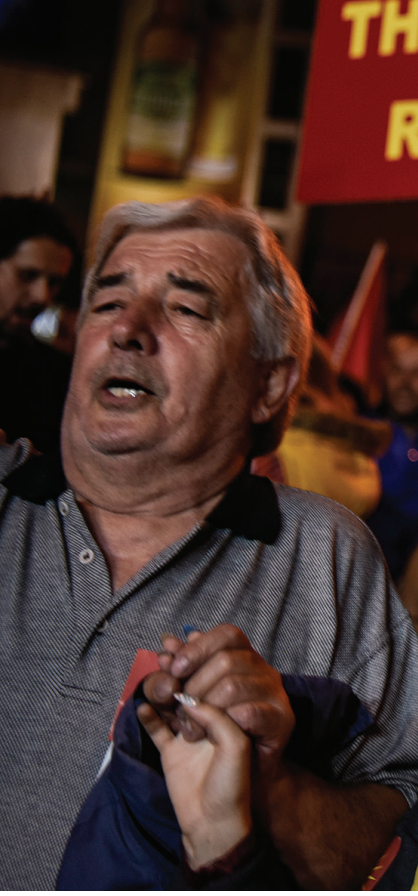

\section{WE ARE ONLY MACEDONIANS}

ALWAYS ANT FOREVEF

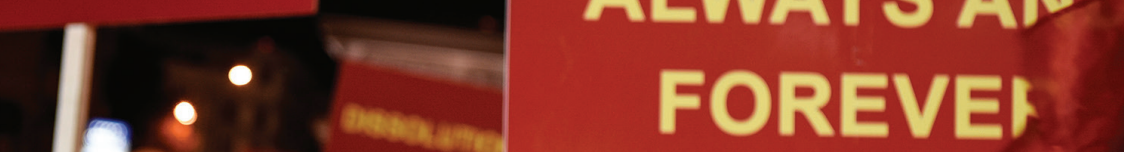

the law (domestic and international), but is also against good customs, as

it is unknown in contemporary politics and law to have a neighbor and/or an international organization ordering you to change the historical and constitutional name of your state, in a neo-colonial manner, in order to open your road toward NATO and the EU, which at the same time keep insisting that for them, respect for the rule of law is modus vivendi and modus operandi. ${ }^{7}$

The right to self-determination is violated as "the only rule in the broad international law is that each state can elect its own name, it can determine its own flag or national coat of arms." ${ }^{\prime \prime}$ A name is the core of not only individual but also collective identity. This right belongs to the Macedonian people, and the sitting Macedonian government is unable to waive the Macedonian people's right to self-determination. The right to the internal self-determination of an entire population of a State is stipulated in the Human Rights Covenants, the UN Friendly Relations Declaration, and other international legal instruments.

While the 1993 UN resolution calls for "a speedy settlement of difference" between Macedonia and Greece over the name, the Prespa Agreement deals with the interpretation of Macedonian history, Macedonian identity, Macedonian language, and culture. It has ramifications on the Constitutional order, political system, and education, and denies the individual and group right to self-determination of Macedonians. The Agreement is in contradiction with Article 118 of the Macedonian Constitution, which states: "The international agreements
Supporters of a boycott for the name-change referendum celebrate in front of the parliament in Skopje on September 30, 2018, as the vote was marred by a low turnout, with only a third of the electorate voting. ARMEND NIMANI / AFP / Getty Images 
The Prespa Agreement violates the right of the Macedonian people to internal self-determination, as it denies the Macedonian people the right to a political regime based on the people's self-identification, as well as to freely pursue social and cultural development an old nation... is the result of the huge change in cultural identification in the $18^{\text {th }}$ century and was consolidated in the $19^{\text {th }}$ century." 11 Yet, Article 8(2) assumes the exclusive right of Greece to ancient Macedonian legacy. Moreover, the Agreement stipulates that the population of the Greek part of Macedonia is 'Macedonian' with links to Alexander the Great and Greek ethno-national consciousness. Macedonians in Greece are thus denied the right to self-identify as Macedonian and their dire position as a minority will be further threatened. As Lorena Lopez de Lacalle, vice-president of the EFA, writes, "if the Macedonian history is to be interpreted and written by Greece, if the Macedonian identity is to be determined by Greece, there will be even less margin for the Macedonian minority in Greece and Bulgaria to state and defend their case." ${ }^{12}$

A separate, Joint Inter-Disciplinary Committee of Experts on historic, archaeological, and educational matters discusses possible "irredentist" content in North Macedonia's school textbooks, maps, and teaching guides, making sure references to ancient Macedonia are embedded in Greek heritage. This is in essence redesigning the next North Macedonian generation's identity. It is doubtful whether such a dramatic reorientation of national identity has ever been undertaken in modern times. ${ }^{13}$ "The special point is that [the Macedonian] national narrative is now being shaped in conversation with Greece," says Ioannis Armakolas. "I don't know if Greeks understand 
how great this is. Imagine another neighbor coming along and deciding with us how we perceive our history and identity." This is an absurd process, as Macedonia should not revise history under pressure. No political agreement should limit the freedom of academic research. Ministries of foreign affairs cannot decide on scientific matters. In the way this Agreement is set up, there is a "danger of state interference in domestic affairs of the weaker party, being exposed to constant political and bureaucratic pressure, hidden in expert cloths." ${ }^{14}$

The Agreement stipulates that "the Second Party shall adopt "Republic of North Macedonia" as its official name and the terminologies referred to in Article 1(3) through its internal procedure that is both binding and irrevocable, entailing the amendment of the Constitution as agreed in this Agreement." This means that the new name is to be used "forever." In international law, no bilateral agreement can produce such effects on a sovereign state as stipulated by Article 1(3). International law imposes limits on contracting by States and on what a government may agree to in an international treaty. According to Article 53 of the Vienna Convention, "a treaty is void if, at the time of its conclusion, it conflicts with a peremptory norm of general international law (ius cogens)." International law penalizes a treaty violating ius cogens by absolute invalidity: the treaty is void, if, at the time of its conclusion, it conflicts with ius cogens. Prohibited treaties include treaties contemplating the use of force, treaties contemplating the commission of genocide or enslavement, treaties violating human rights, the equality of States, or the right to self-determination. Therefore, "nobody can forbid Macedonians to change imposed constitutional provisions which are contrary to the ius cogens." 15 In Greece itself, "even though the Greek Constitution from 1968 banned the abolishment of monarchy, in 1974 the Greek people decided in a referendum to do just that and to introduce a republic under a new Constitution."16 The Agreement cannot deny the right of Macedonian lawmakers to change the Constitution.

A government specifically cannot waive the right of its population to self-determination. The Agreement conflicts with the right of the people of Macedonia to self-identification and self-determination (Article 1(3)). Article 3(4) effectively prohibits civil activity relating to Macedonian identity and culture in the Republic of Macedonia, including democratic discussion on the matter and expressions of Macedonian identity and culture, as these could be characterized as "unfriendly," "subversive," or "stability-threatening." ${ }^{17}$ As such, the Prespa Agreement violates the right of the Macedonian people to internal self-determination, as it denies the Macedonian people the right to a political regime based on the people's self-identification, as well as to freely pursue social and cultural development. The Agreement additionally violates the political and cultural rights of Macedonians as protected under international human rights law. Individual Macedonian nationals 
could file applications alleging the violation of their rights in international human rights courts and complaint mechanisms, such as the European Court of Human Rights, the Human Rights Committee, the so-called "1503 procedure" of the UN Human Right Council, and with various Special Rapporteurs appointed by the UN Human Rights Council (for example, in the field of cultural rights; on the promotion and protection of the right to freedom of opinion and expression; and on the rights to freedom of peaceful assembly and of association).

Ironically, even with the name change, there is no guarantee that Macedonia will accede to the EU. Even if it begins accession talks in the summer of 2019, the road to EU integration might be very long. In the most optimistic scenario, Serbia and Montenegro, which are already in accession talks with the European Commission, are expected to join the EU in 2025. Greece will have to give a positive signal for every negotiating chapter of the EU accession negotiations. A future Greek government could ask for further concessions. Article 2 of Prespa specifies that Greece will not object to Macedonia submitting an application for membership under the new name in international and regional organizations and institutions where Greece is already a member. Yet, this exact clause was also included as Article 11 of the 1995 Interim Accord; its legitimacy was confirmed by the International Court of Justice in the Hague in 2011 in its verdict, which found that Greece violated the Accord, but
Greece still stopped Macedonia from acceding to NATO until 2018. For example, Greece could raise issues related to the implementation of the Prespa Agreement and the honoring of the letter and the spirit of the text. The most likely winner of the next Greek elections, New Democracy, "is already pondering a tougher policy on the EU accession process in view of its expected coming to power." ${ }^{18}$

Macedonia has a legitimate right to its name and identity. This right is based on various arguments, be they legal, moral, historical, or grounded in liberal-democratic ideas. The Prespa Agreement led to changes to the name of the country. This Agreement was passed with numerous procedural and legal irregularities. Moreover, the referendum on the Agreement did not produce a majority to approve it. Not only the Agreement violates Macedonia's right to self-determination but also interferes with the interpretation of Macedonian history, identity, language, and culture. Against international law, the Agreement stipulates that is both binding and irrevocable. It does not even guarantee further Greece blockages in the EU accession process. For all these reasons the Prespa Agreement is not a solution to the so-called Macedonian name dispute.

\section{Endnotes}

1. International Covenant on Civil and Political Rights (ICCPR), Article 1.

2. Reimer Larry, "Macedonia: Cultural Right or Cultural Appropriation?" University of Toronto Faculty of Law Review, No. 53 (1995), p. 359. 
3. Matthew C. R. Craven, "What's in a Name? The Former Yugoslav Republic of Macedonia and Issues of Statehood," first published in Australian Year Book of International Law, Vol. 16, (1995), p. 238, republished in Donald R. Rothwell, Stuart Kaye, Afshin Akhtarkhavari, and Ruth Davis (eds.), International Law: Cases and Materials with Australian Perspectives, (Cambridge: Cambridge University Press, 2010).

4. Froomkin, A. Michael, "When We Say US', We Mean It!" Houston Law Review, Vol. 41. No. 3 (2004), pp. 840-841.

5. Henkin Louis, Richard C. Pugh, Oscar Schachter, and Hans Smit, International Law: Cases and Materials, $3^{\text {rd }}$ Edition, (Westgroup: New York City and Berkeley, 1993), p. 253.

6. "Ivanov Fails to Sign Law Ratifying Name Agreement," European Western Balkans, (June 26, 2018) retrieved from https://europeanwesternbalkans. com/2018/06/26/ivanov-fails-sign-law-ratifying-name-agreement/.

7. Siljanovska Davkova Gordana, "On the 'Prespa Agreement' and Beyond," Nova Makedonija, (2018), p. 10.

8. Crawford James, Verbatim Record of Oral Proceedings in the Case Concerning Application of the Interim Accord of 13 September 1995 (the Former Yugoslav Republic of Macedonia v. Greece), CR2011/12, (March 30, 2011), retrieved from https://www.icj-cij.org/files/case-related/ 142/142-20110330-ORA-01-00-BI.pdf, p. 32.

9. See, Boyle Francis, "Vienskata Konvencija Mozhe da go Urne Dogovorot [Vienna Convention Can Overturn the Agreement]," Nova Makedonija, (February 2, 2019).

10. Messineo Francesco, "The ICJ and the Macedonian Dispute," Cambridge Journal of International and Comparative Law, Vol. 1, No. 1 (2012), p. 172.
11. Liakos Antonis, "Historical Time and National Space in Modern Greece," in Hayashi Tadayuki and Hiroshi Fukuda (eds.), Regions in Central and Eastern Europe: Past and Present, (Sapporo: Slavic Research Centre, 2007), p. 218.

12. "EFA: Prespa - A Dangerous Agreement," MHRMI, (June 20, 2018), retrieved from http:// mhrmi.org/news/2018/june20_e.asp.

13. John Psaropoulos, "Name Row: Greece, North Macedonia Have Work Cut Out for Them," Al Jazeera, (January 31, 2019), retrieved from https:// www.aljazeera.com/indepth/features/rowgreece-north-macedonia-work-cut-190131080 808299.html.

14. Gordana, "On the 'Prespa Agreement' and Beyond," p. 12.

15. Gordana, "On the 'Prespa Agreement' and Beyond," p. 16.

16. Gordana, "On the 'Prespa Agreement' and Beyond," p. 14.

17. Under Article 3(4) of the Agreement: "The Parties commit not to undertake, instigate support and/or tolerate any actions or activities of a non-friendly character directed against the other Party. Neither Party shall allow its territory to be used against the other Party by any third country, Organization, group or individual carrying out or attempting to carry out subversive, secessionist actions, or actions or activities which threaten in any manner the peace, stability or security of the other Party."

18. Armakolas loannis, Igor Bandovic, Dimitar Bechev, and Bodo Weber, "North Macedonia: What's Next?" Open Society, European Policy Institute, (January 2019), retrieved from https://www. opensocietyfoundations.org/reports/northmacedonia-what-s-next, p. 19. 
